\title{
Irrigation of the cultivated area with groundwater from vertical drainage wells
}

\author{
Zulfiya Mirkhasilova ${ }^{1 *}$, Murat Yakubov $^{2}$, and Lyudmila Irmuhamedova ${ }^{1}$ \\ ${ }^{1}$ Tashkent Institute of Irrigation and Agricultural Mechanization Engineers, Tashkent, Uzbekistan \\ ${ }^{2}$ Research Institute of Irrigation and Water Problems, Tashkent, Uzbekistan
}

\begin{abstract}
In recent years, there has been a shortage of water resources in the basins of the Amu Darya and Syrdarya rivers, which is the result of the development of new lands for irrigation and the inappropriate use of water and land resources.

A side effect of irrigation and land reclamation is the increasing flow of collector-drainage waters every year, which leads to a deterioration in the land reclamation state and pollution of water resources, which can lead to the ecological disaster of land and water resources. Currently, in the Republic of Uzbekistan, from the total volume of water resources of the Amu Darya and Syrdarya rivers, up to $68 \%$ is used for irrigation. Of this volume on the Republic territory, about $12 \%$ of collector-drainage waters of deteriorated quality are formed. With a shortage of water resources, they are used for irrigation. But irrigation with saline waters can lead to a deterioration in the land reclamation state. In this regard, new irrigation technologies are proposed, which can save both irrigation water and it is advisable to use underground pumped water for irrigation.

Field experiments were carried out in the farm "Khozhilkhon-hozhi" in the farm named after A. Niyazov, Kuva district, Fergana region. A feature of the soil conditions in this farm is the small thickness of the covered fine earth, underlain by highly permeable gravel, strong and increased water permeability, with a deep groundwater level $(\mathrm{GWL}>3 \mathrm{~m})$.

Large water losses are observed during irrigation. The calculation task was to determine how many hectares of land can be irrigated from one vertical drainage well, taking into account the irrigation time, inter-irrigation period, etc.

The water-salt balance of the reclaimed lands for 2017-2019 was compiled. The water-salt balance showed that water supply and filtration from canals and atmospheric precipitation play the main role in the inlet part. In the consumable part, the main place is occupied by evapotranspiration and drainage flow. In general, a negative balance is formed on the territory annually by the type of a small salt carryover within $2.85 \mathrm{t} / \mathrm{ha}$. On the territory of the farm and the experimental plot, cotton of the S-6524 variety was sown, the flow rate of the well is $301 / \mathrm{s}$, the furrow consumption is $0.51 / \mathrm{s}$. The composition of hypothetical salts in the pumped-out waters is calculated

After the first irrigation of our field, the pumped-out water is diverted to the neighboring fields, while the first inter-irrigation period is 20 days. In the interval of these 20 days until the second irrigation of the cotton of the
\end{abstract}

\footnotetext{
* Corresponding author: mzulfiya.k@mail.ru
} 
original field, it is possible to irrigate the same fields 5 hectares 8 times, in total 40 hectares of land.

The experiments showed that irrigation with pumped water from vertical drainage wells did not have a negative impact on the yield of cotton. And the use of the recommended irrigation technology will reduce the shortage of irrigation water and improve the ecological situation of water resources.

\section{Introduction}

The development of the use of water resources for irrigation and industrial needs leads to a shortage of fresh water and a deterioration in the land reclamation state. A side effect of irrigation and land reclamation is the increasing flow of collector-drainage waters every year, which leads to a deterioration in the land reclamation state and pollution of water resources.

Currently, in the Republic of Uzbekistan, from the total volume of water resources of the Amu Darya and Syrdarya rivers, up to $68 \%$ is used for irrigation. From this volume on the Republic territory, about $12 \%$ of collector-drainage waters of deteriorated quality are formed; the salinity of these waters ranges from $2 \mathrm{~g} / \mathrm{l}$ to $10 \mathrm{~g} / \mathrm{l}$. Depending on the mineralization, the toxicity of salts in drainage waters also changes. Collector-drainage waters up to $2 \mathrm{~g} / \mathrm{l}$ contain up to $20 \%$ toxic salts, including salts of chlorine, sodium and pollutants - phenols and petroleum products. With an increase in mineralization up to $16-20 \mathrm{~g} / 1$, toxic substances make up $50 \%$ of the total composition of drainage water salts.

Many scientists from different countries of foreign countries and Central Asia had experience in working with drainage waters. The works of the following authors are devoted to the establishment of the general reserves of groundwater and the possibility of using them for water supply and irrigation of crops, as well as the assessment of the replenished operational reserves: N. Reshetkina; H. Yakubov, G. Mavlyanova, S. Mirzeva, N. Plotnikova, M. Zaparia, L. Krasilshchikova; S. Mukhamedzhanova; V.Usenko, M. Chaban, I. Trukhan, A. Usmanov, T. Bekmuratova, R. Ikramov, M. Khamidov, Sh. Mukhamedzhanov, A. Karimov, A. Salokhitdinov and others [1-7].

Assessment of the quality of various natural waters and the results of determining their applicability for irrigation of agricultural crops indicate the possibility of using saline waters for irrigation and leaching of saline lands

According to most studies, to obtain a high and stable yield, the permissible concentration of salts in soil solutions with a chloride-sulfate composition of salts typical for most of the irrigated soils of Central Asia should not exceed 6-7 g/l.

At a concentration of 6-12 $\mathrm{g} / \mathrm{l}$, the yield of cultivated crops is satisfactory.

An increase in the concentration of soil solutions beyond 10-12 g/l causes inhibition of most agricultural plants. At a concentration of $20-25 \mathrm{~g} / \mathrm{l}$ and above, their growth and development are suspended. At the same time, the concentration of soil solutions for Fergana conditions with a pronounced sulfate salinity - up to $10-13 \mathrm{~g} / \mathrm{l}$ does not have a physiologically harmful effect on a crop such as cotton [8-12].

An analysis of the above literature data shows that when using drainage water in certain regions with different climatic, hydrogeological, soil and agromeliorative conditions against the background of various crops and drainage, a satisfactory crop yield was obtained with different degrees of irrigation water salinity. The permissible limit of applicability ranges from 2 to $5 \mathrm{~g} / \mathrm{l}$, depending on the chemical composition of water and irrigation conditions.

Many researchers - V.A. Kovda, V.V. Egorov, D.M. Katz, I.S. Rabochev, N.M. Reshetkina and others; Kh.I. Yakubov, L.L. Korelis, A.Usmanov, T.U. Bekmuratov, R.K. Ikramov, M.A. Yakubov and others note that when using saline pumped out and collector-drainage waters for irrigation and obtaining satisfactory crop yields, it is necessary to create a flushing irrigation regime [13-18].

Even though many scientists were engaged in the irrigation of collector and drainage waters, irrigation with groundwater pumped from vertical drainage wells in the zone of their pinching was not 
considered.

\section{Methods}

For scientific research, the statistical method and the method of conducting field experiments at the experimental site were used.

\section{Results and Discussion}

To improve the ecological situation of water resources, to improve the reclamation state of irrigated lands, field experiments were carried out. The field study aimed to irrigate with pumped water without discharging it into the drainage network.

For this, it was necessary to study the example of a specific farm. Field experiments were carried out in the farm "Khozhilkhon-hozhi" in the farm named after A. Niyazov, Kuva district, Fergana region. A feature of the soil conditions in this farm is the small thickness of the covered fine earth, underlain by highly permeable gravel, strong and increased water permeability, with a deep groundwater level (GWL> $3 \mathrm{~m}$ ). Large water losses are observed during irrigation [18-30].

The field research task was to determine how many hectares of land can be irrigated from one vertical drainage well, taking into account the irrigation time, the inter-irrigation period. To carry out field studies, it was necessary to calculate the water-salt balance of the territory.

Table 1. Actual general water-salt balance in WUA conditions "AND. Niyazov "(average for 20172019)

\begin{tabular}{|c|c|c|c|}
\hline$№$ & Elements of water-salt balance & Water, $\mathrm{m}^{3} / \mathrm{ha}$ & Salt, $\mathrm{t} / \mathrm{ha}$ \\
\hline 1 & Water supply (gross) & 8030 & 5.46 \\
\hline 2 & Precipitation & 1680 & 0.67 \\
\hline 3 & Filtering from channels & 3280 & 2.23 \\
\hline 4 & Evapotranspiration & 7820 & - \\
\hline 5 & Discharges from the fields & 1930 & 1.31 \\
\hline 6 & Underground inflow and outflow & 1840 & 0.74 \\
\hline 7 & Drainage drain & 6610 & 10.64 \\
\hline 8 & Changes in moisture and salt reserves & -1530 & -2.85 \\
\hline
\end{tabular}

The water-salt balances of reclaimed lands compiled by us for 2017-2019 showed that the main role is played by water supply and filtration from canals and atmospheric precipitation in the inlet part. In the consumable part, the main place is occupied by evapotranspiration and drainage flow. In general, a negative balance is formed on the territory annually by the type of a small salt removal within the range of $2.85 \mathrm{t} /$ ha (Table $1)$.

On the territory of the farm and the experimental plot, cotton of the S-6524 variety was sown, the flow rate of the well is $301 / \mathrm{s}$, the furrow flow rate is $0.51 / \mathrm{s}$, the value of the longitudinal slope is 0.012 , the number of simultaneously irrigated furrows is 20 pcs.

Along the length of the longitudinal irrigated area, there are three irrigated areas separated by furrows; the number of simultaneously irrigated furrows is 20 . Water from the head water intake is taken in portions from furrows connected to irrigation. Watering starts with filling 20 furrows of the upper section. Then the second section is refueled. With 20 furrows, it has a water intake of $10 \mathrm{l} / \mathrm{s}$, the discharge from the left section is $21 / \mathrm{s}(20 \%)$, and in the second section, 4 furrows are additionally provided due to the discharge.

After the first irrigation of our field, the pumped-out water is diverted to the 
neighboring fields, while the first inter-irrigation period is 20 days. In the interval of these 20 days until the second irrigation of the cotton of the original field, it is possible to irrigate the same fields 5 hectares 8 times, in total 40 hectares of land.

During the growing season, irrigation rates were 900-1200 $\mathrm{m} 3 /$ ha. Watering was assigned according to humidity $70-70-65 \%$ of HB. In experiments using the SANIIRI methodology, the following questions were studied: change in the water-physical properties of the soil during irrigation of cotton with pumped water; study of the salinity of pumped out and ditch water and chemical composition; change in the content of salts in the aeration zone according to the variants of the experiment; dynamics of the level and mineralization of groundwater; changes in the elements of the water-salt balance; study of the effect of water mineralization on the yield of cotton.

The irrigation rate of the main crop, cotton, for the experimental plot was calculated using the formula of S.N. Ryzhov:

$$
m=\left(W_{n v}-W_{f}\right) \cdot 100 \cdot \gamma \cdot h+k, m 3 / g a
$$

here $W_{n v}$ is the smallest soil moisture capacity,\% of the mass; Wf is the actual soil moisture before irrigation, $\%$ of the mass; $\gamma$ is bulk density of soil, $g / \mathrm{cm} 3 ; \mathrm{h}$ is calculated layer, $\mathrm{m}$; $\mathrm{k}$ is water consumption for evaporation during irrigation $(10 \%)$ of moisture deficit in the calculated layer. The soil on our site is medium loamy. Irrigation and irrigation rates supplied from vertical drainage and control wells irrigated with ditch water are given in Table 2.

Table 2. Irrigation and irrigation rates in the experimental and control field

\begin{tabular}{|c|c|c|c|c|}
\hline \multirow{2}{*}{ Options } & \multicolumn{3}{|c|}{ highest moisture content } & \multirow{2}{*}{ Irrigation rate } \\
\cline { 2 - 4 } & $70 \%$ & $70 \%$ & $65 \%$ & 3150 \\
\hline Arychna water & 900 & 1100 & 1150 & 3300 \\
\hline Pumped water & 950 & 1150 & 1200 & \\
\hline
\end{tabular}

Irrigation and irrigation rates for the two options were close in terms and rates that were used in production conditions. To study the quality of the pumped water, water samples were taken from vertical drainage wells. The salinity of the pumped-out water ranged from 1.2 to $3.1 \mathrm{~g} / 1$. Sulfate ions prevail in the composition of anions, magnesium and sodium prevail in the composition of cations. Based on statistical processing of materials of chemical analysis of pumped water, a graph of the dependence of anions and cations on the value of mineralization was obtained, Figure 1.

The composition of hypothetical salts in the pumped-out waters was calculated, the results of which made it possible to reveal the dependence of the sum of non-toxic CaSO4, $\mathrm{Ca}(\mathrm{HCO} 3) 2$ and the sum of toxic (MqSO4, Na2SO4, NaCL) salts on water salinity, Figure 1. From the calculated calculations, it can be seen that with an increase in water salinity over 1.6-1.8 g/ 1 , the amount of toxic salts increases, which were approximately equal with mineralization of $1.2-1.4 \mathrm{~g} / 1$. 


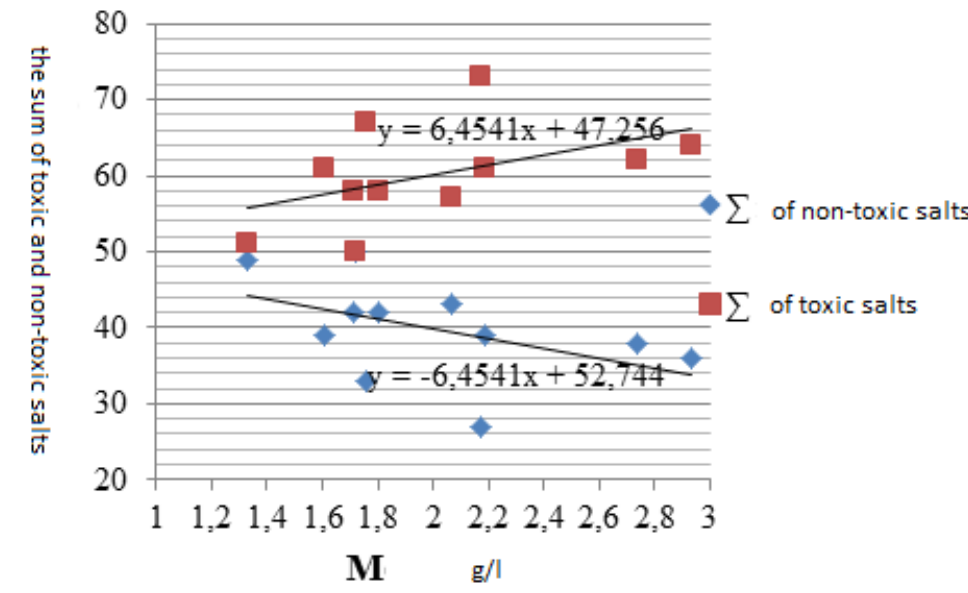

Fig. 1. Sum of toxic, non-toxic salts

According to the classification of suitability for irrigation, it was shown that these waters are suitable for irrigation (Table 3).

Table 3. Assessment of the quality of ditch and ground water used for irrigation by various methods

\begin{tabular}{|c|c|c|}
\hline Assessment methods & $\begin{array}{c}\text { River water with } \\
\text { average mineralization } \\
\text { of } 0.680 \mathrm{~g} / 1\end{array}$ & $\begin{array}{c}\text { Groundwater with } \\
\text { average } \\
\text { mineralization of } \\
2.540 \mathrm{~g} / 1\end{array}$ \\
\hline According to M.F. Budanov & 0.33 & 0.69 \\
\hline According to A.M. Mozheiko & 24.90 & 40.91 \\
\hline Collar T.K. & 2.84 & 1.40 \\
\hline $\begin{array}{c}\text { According to Antipov-Karataev } \\
\text { I.N. and Kader G.M. }\end{array}$ & 38.92 & 64.81 \\
\hline
\end{tabular}

\section{Conclusions}

The results of the experiments showed that changes in the water-salt regime of soils and irrigation with low-mineralized pumped water $\left(\mathrm{M}_{\text {otk }}^{s r}=1.5-2.5\right.$ г/л $)$ against the background of the adopted regime and norms of irrigation, normal agrotechnical and organizational methods did not have a negative impact on cotton yield.

On the experimental site, an average yield was achieved in the range of 26.4-26.5 c / ha. On the control plot, with irrigation ditches, the yield was slightly higher: 26.7-27 c / ha; that is, the difference in plant productivity in the two plots was small.

A field experiment showed that after the first irrigation of our field, the pumped water is diverted to the neighboring fields; if the first inter-irrigation period is 20 days, then before the second irrigation of cotton, the same fields can be irrigated 5 ha 8 times, i.e. 40 ha of land. The new irrigation method shows that the use of these technologies will reduce the shortage of irrigation water and improve the ecological state of water resources. 


\section{References}

1. Mirkhasilova Z., Irmuhamedova L., Kasymbetova S., Akhmedjanova G. Mirkhosilova M. Rational use of collector-drainage water 2020 IOP Conf. Ser.: Mater. Sci. Eng. 883, (2020)

2. Saidhujaeva N., Nulloev U., Mirkhasilova Z., Mirnigmatov B., Irmukhamedova L. Production of Plant Product as a Process of Functioning Biotechnical System, 9 (1), (2019)

3. Mirkhasilova Z.K, Ways to improve the water availability of irrigated lands. European science review (7-8), ( 2018)

4. Kostovarova I. A., Shlenov S. L., Zamakhovsky M. P. Irrigation Effectiveness Improvement Using Multifunctional. Watering Method. Dostizheniya nauki i tekhniki APK. 33. (3). pp. 58-61, (2019), doi: 10.24411/0235-2451-2019-10315.

5. Turapin S.S., Kostovarova I.A. Modern problems and perspective ways of increase in efficiency and reliability of wide-cut sprinkling machine, Ekologiya $\mathrm{i}$ stroitelstvo, 3, pp. 17-26, (2018), doi: 10.24411/2413-8452-2018-10011

6. Kostovarova I.A. Production experience of the cultivation of precocious cotton varie-ties after winter wheat harvest under sprinkler irrigation, Ekologiya i stroitelstvo, 2, pp. 49-57, (2019), doi: 10.35688/2413-8452-2020-02-007. (2019).

7. Mirkhasilova Z., Irmuhamedova L., Akhmedjanova G., Tursunova D. Transfer of vegetable water flows for full support of drained water from wells of vertical drainage. International journal of advanced research in science, engineering and technology. 6,(5), pp 9424-94262, (2019)

8. Bazarov D., Vatin N., Obidov B., and Vokhidov O. Hydrodynamic effects of the flow on the slab of the stand in the presence of cavitation. IOP Conf. Ser. Mater. Sci. Eng. 1030, 012110 (2021).

9. Hamidov, A, Khamidov, M.; Ishchanov, J, Impact of Climate Change on Groundwater Management in the Northwestern Part of Uzbekistan. Agronomy, 10, p 1173. https://doi.org/10.3390/agronomy10081173. (2020)

10. Khojiyev A., Muradov R. Vlago $i$ soleperenos $v$ nachalniy period razvitiya rasteniy, The Way of Science, International scientific journal, 8 (54) pp. 50-54, Volgograd, Russia, (2018)

11. Bazarov D., Markova I., Norkulov B. and Vokhidov O. Hydraulic aspects of the layout of head structures during water intake from lowland rivers. IOP Conf. Ser. Mater. Sci. Eng. 1015, 012041 (2021).

12. Khojiyev A., Muradov R., Khaydarov T., Rajabov N., Utepov B. Some results of moisture and salt transfer in the initial period of plant development. International Journal of Engineering and Advanced Technology (IJEAT), 9, pp. 6907-6911 India, (2019)

13. Bazarov D., Markova I., Sultanov S. and Kattakulov F. Dynamics of the hydraulic and alluvial regime of the lower reaches of the Amudarya after the commissioning of the Takhiatash and Tuyamuyun hydrosystems. IOP Conf. Ser. Mater. Sci. Eng. 1030, 012110 (2021).

14. Khojiyev A., Khaydarov T., Rajabov N., J.Pulatov. Optimal solution leaching rates with a deficit of irrigation water, IOP Conf. Series: Materials Science and Engineering 883, (2020)

15. Bazarov D. and Vokhidov O. Extinguishing Excess Flow Energy in Spillway Structures. In book: Proceedings of EECE 2020, LNCE 150, pp. 535-545, (2021) DOI: 10.1007/978-3-030-72404-7_52

16. Khojiyev A., Muradov R.A., Khaydarov T., J.Pulatov. Changes in the exchange of salt and moisture in groundwater management. IOP Conf. Series: Materials 
Science and Engineering 883 (2020) (2020)

17. Avliyakulov M., Durdiev N., Rajabov N., Gopporov F., Mamataliev A. The changes of cotton seed-lint yield in parts of furrow length under different irrigation scheduling, Journal of Critical Reviews 7, (5), 2020, pp. 838-843, (2020)

18. Obidov B., Vokhidov O., Tadjieva D., Kurbanova, U., Isakov A. Hydrodynamic effects on the flow elements of the downstream devices in the presence of cavitation. IOP Conf. Ser. Mater. Sci. Eng. 1030, 012114 (2021).

19. Mirzoolim A. Avliyakulov, Mamta Kumari, Nurmamat Q. Rajabov, Normat Kh. Durdiev. Characterization of soil salinity and its impact on wheat crop using space-borne hyperspectral data, 26, (3), pp. 271-285, (2020)

20. Bazarov D., Norkulov B., Vokhidov O., Uljaev F., Ishankulov, Z. Twodimensional flow movement in the area of protective regulatory structures. IOP Conf. Ser. Mater. Sci. Eng. 890, 012162 (2020)

21. Saidhujaeva N. Research of the rheological properties of melon as an elastic deforming body. International Journal of Psychological Rehabilitation. 24, (07), pp. 8143-8148, (2020)

22. Z.Iskandarov, N.Saidkhujaeva, G.Abdieva, M.Karimullaeva, Machine for cutting melons on ring-sheeds, International Journal of Advanced Research in Science, Engineering and Technology, 6,(4), (2019)

23. Krutov A., Choriev R., Norkulov B., Mavlyanova D. and Shomurodov A. Mathematical modelling of bottom deformations in the kinematic wave approximation. IOP Conf. Ser. Mater. Sci. Eng. 1030, 012147 (2021).

24. Krutov A., Norkulov B., Mavlyanova D. Simulation of spreading of nonconservative passive substances in water bodies. IOP Conf. Ser. Mater. Sci. Eng. 883(1), 012028 (2020)Khasanov B., Irmukhomedova L., Firlina G., Mirzaev T. Theoretical foundations of the structure formation of cement stone and concrete. IOP Conference Series: 2020 IOP Conf. Ser.: Mater. Sci. Eng. 883, (2020)

25. Shokirov B., Norkulov B., Nishanbaev Kh., Khurazbaev M., Nazarov B. Computer simulation of channel processes. E3S Web of Conferences, 97, 05012, (2019)

26. Sanbetova A., Sulliev A. and Kasimov Sh. Research on Biparametric Resonant Dichlacement Sensors, IOP Conf. Ser.: Mater. Sci. Eng. 883, (2020) doi:10.1088/1757-899X/883/1/012150

27. Matyakubov B., Begmatov I., Raimova I. and Teplova G. Factors for the efficient use of water distribution facilities. IOP Conf. Ser. Mater. Sci. Eng. 883, 012025 (2020).

28. Matyakubov B. "Efficient use of water in the Khorezm Oasis". International journal of innovations in engineering research and technology, 5, (11), pp. 44-49, (2018)

29. Uralov B., Rakhmatov N., Khidirov S., Uljaev F., Raimova I. Hydraulic modes of damless water intake. IOP Conf. Ser. Mater. Sci. Eng. 1030(1), 012123 (2021)

30. Bazarov D., Markova I., Raimova I., Sultanov Sh. Water flow motion in the vehicle of main channels. IOP Conf. Ser. Mater. Sci. Eng. 883, 012025 (2020). 